\title{
Review Article \\ Museum Studies, Area Studies, and Museums in China
}

\author{
Elizabeth Lawrence*
}

Kirk A. Denton, 2014, Exhibiting the Past: Historical Memory and the Politics of Museums in Postsocialist China, Honolulu: University of Hawai'i Press, hardback, viii+350pp, $\$ 59.00$

\begin{abstract}
Marzia Varutti, 2014, Museums in China: the Politics of Representation after Mao, Woodbridge: The Boydell Press, hardback, 203pp, $\$ 99.00$
\end{abstract}

Since the turn toward the 'new museology,' museum studies has emerged as 'one of the most genuinely multi- and increasingly inter-disciplinary areas of the academy today' (Macdonald 2011: 1). Museum and Society foregrounds this interdisciplinary remit. But my own field has long been less forgiving of discipline-crossing transgressors. A historian of modern China, my PhD is in East Asian Languages and Cultures, or in other words, area studies. Critics have called area studies 'the main custodian of an isolating system of disciplinary knowledge' (Harootunian and Miyoshi 2002: 8). With Cold War origins, area studies traditionally emphasized language mastery and command of regional, often national, expertise over the production of scholarship with cross-disciplinary and cross-regional valences. While many have challenged this insularity, area studies specialists still have a tendency to act as gatekeepers. Book reviewers, for instance, will highlight mistranslations to undermine an author, without explicitly connecting the translation errors to the book's larger arguments. Meanwhile, the very real demands of language training and regional expertise make some area studies specialists unwilling or unable to broaden their disciplinary horizons.

Given the persistent tendencies toward insularity in area studies, how refreshing it is to welcome two richly interdisciplinary books on museums in China by Marzia Varutti and Kirk Denton. The authors both bring outsider perspectives to their shared topic. Varutti is not a China specialist. In Museums in China, she anticipates criticism by foregrounding her limitations as a speaker and reader of Chinese: 'my language skills were not advanced enough to enable me to conduct structured research interviews in Chinese nor to read specialised literature without help (5-6).' Denton, for his part, embarked on the research for Exhibiting the Past with commanding regional expertise but no formal training in museum studies. In his own words, his 'entry into this new scholarly terrain has involved extensive readings in fields I knew little about and some I never even knew existed' (vii).

I am pleased to write that the discipline transgressing scholarship of these authors has resulted in two quality books. To be sure, Varutti mistranslates certain terms. Her larger argument has been shaped by her lack of deep training in Chinese studies. And Denton, as a China expert, occasionally speaks past the non-specialist reader. But both books have strengths that outweigh their weaknesses, and surely, the fact that they do have weaknesses, weaknesses that are complemented by the strengths of the other, indicates that gatekeeping is untenable and that the gates should be removed from their hinges. As museums proliferate across China and other locales less studied by English-language scholars, let us encourage free and open movement between the edifices of museum studies and area studies.

Marzia Varutti's compact book focuses on contemporary Chinese museums with an eye to how they have developed since the 1980s, when China began its transition away from socialism toward an embrace of globalization and capitalism under the guidance of the Chinese Communist Party (CCP). Museums in China broadly surveys 'museums... dealing with aspects of the Chinese nation, specifically the presentation of the national past and of national identity' 
(5). Varutti sees these museums as tools of nation-building and state legitimation that have set aside Maoist political orthodoxy to embrace cultural nationalism.

According to Varutti, contemporary Chinese museums present objects as embodiments of a particular vision of the Chinese nation as ancient, continuous, glorious, and worthy of pride. Breaking with revolutionary narratives, historical context is avoided in favor of messages emphasizing timeless cultural unity. Of all the outside literature that Varutti usefully draws on, she is most indebted to Stephen Greenblatt's concepts of 'resonance' and 'wonder.' Greenblatt defines wonder, as cited by Varutti, as "the power of the displayed object to stop the viewer in his or her tracks, to convey an arresting sense of uniqueness, to evoke an exalted attention"' (64). Varutti contends that Chinese museums have increasingly emphasized this wonder effect by highlighting the aesthetic properties of objects. It is this idea that she returns to in her conclusion, where she posits that aesthetics is 'one of the elements that has come to indicate modernity in museums most strongly' (161).

Of course, not all Chinese museums draw on the aestheticizing strategy equally. The Shanghai Museum, with its soft lighting and reverential atmosphere, exemplifies the trend (64-66). The National Museum of China, with its exhibit on recent history, combines 'MarxistLeninist museology and decontextualizing and aesthetisizing approaches' (114). Meanwhile, museums of culture, industry, and science, explored in chapter 8 , appear rather more dependent on blatant narratives, not aesthetics, to communicate their nationalistic messages. From a wall label at the Tobacco Museum we learn, for instance, that tobacco 'has integrated with Chinese traditional culture, leading to the birth of the rich and colorful tobacco culture' (124). No amount of intimate lighting will turn a cigarette into a metonym of the nation. A fuller consideration of the aesthetic approach as it relates to the whole spectrum of Chinese museums analyzed by Varutti would be welcome.

It may well be that Varutti emphasizes the aesthetic approach because she herself is less sensitive to the historical and cultural resonances that particular museum objects and particular museums - such as those devoted to Japanese wartime atrocities - evoke for Chinese audiences. Varutti devotes chapter 8 to museum representations of the past, but beyond an analysis of the National Museum of China, she has little to say about the genre of museum that is central to Denton's book: museums and memorial sites focusing on recent Chinese history. These museums also employ aesthetic approaches at times, but they cannot skirt what Denton calls the "political minefield" of modern history by avoiding contextualizing narratives (10). They must face, head on, the ambiguities of representing, and making relevant, China's revolutionary past.

Denton's book, with its more defined topic and deeper engagement with China-specific scholarship, provides a sensitive exploration of museums as "sites of memory" (11). The chapters are organized around museum type, allowing for convenient sampling based on individual interests. Topics range from China's more conservative military museums (chapter 4) to nostalgia-laden red tourism sites (chapter 10). Much like Varutti, Denton views these postsocialist Chinese museums as institutions dominated by narratives aimed at stoking nationalism and legitimizing the state. But even as he focuses on the intended messages of museums, Denton conveys the complexities of exhibits that must engage visitors who bring their own expectations to the museum experience. Both official and vernacular forms of memory, in complex interplay, have shaped these expectations, as have the consumer cultures of China's market economy.

Consider, for instance, Chongqing's Red Crag Revolutionary Memorial Hall (78-84). Red Crag Village was a Communist Party headquarters during the wartime years before the CCP 'liberated' China. Its place in historical memory is cemented by nearby massacres of leftist prisoners orchestrated by the Nationalist army on the eve of their final defeat by CCP forces in 1949. Through this one site, Denton demonstrates the coexistence, in contemporary China, of conventionally pedagogic museum exhibitions and immersive heritage settings featuring multimedia installations geared toward entertainment and a taste for nostalgia. $\mathrm{He}$ further discusses the impact of a Mao-era historical novel and related film on visitor reception. Products of an earlier era of cultural propaganda, the novel and film have indelibly shaped popular perceptions of 'Red Crag' in ways that differ from the priorities of contemporary nationalistic narratives. 
Denton's book overflows with similarly insightful analyses and deserves a broad readership. Yet some readers with minimal background in Chinese studies may find parts of the book difficult because Denton assumes too much prior knowledge. In a chapter on museums of modern literature, Denton barely discusses actual works of literature, despite or perhaps because this is his primary area of expertise. The chapter imagines a reader already familiar with the oeuvre of Lu Xun, China's most famous modern author, and capable of understanding casual references to, for instance, 'the kinds of characters who populate the works of Zhang Ailing' (194). As a historian of China, I know the frustration that such criticism brings. China studies specialists must define their terms and provide context in ways not required of scholars focusing on Euro-America, due to the phenomenon Dipesh Chakrabarty has called 'asymmetric ignorance' (2000: 28). Still, the extra effort to speak to a non-specialist readership must be taken to combat area studies' vestiges of insularity. Denton, to his credit, demonstrates command of an inter-disciplinary body of scholarship, enriches his analysis with global comparisons, and more often than not, as in the Red Crag case study, provides just the right amount of contextualizing detail while making larger points about memory, exhibitionary practices, and reception. The chapter on literature museums, however, is a missed opportunity.

Exhibiting the Past is stronger in the subsequent chapter on ethnographic museums. Denton begins the chapter by situating ethnographic museums in China in a global context, citing research on institutions ranging from the Museum of the American Indian to what is now called the Russian Museum of Ethnography (199-201). He then provides China-specific background, discussing the history of PRC policy toward ethnic minorities and portrayals of Chinese ethnic groups in popular culture (201-204). Finally, he discusses in turn ethnic minority theme parks and ethnic minority ecomuseums. Readers unfamiliar with this distinctively Chinese type of theme park are sure to be fascinated by the analysis of the Chinese Ethnic Culture Park in Beijing (207-210), which presents visitors with recreated ethnic villages populated by traditionally garbed 'villagers.' The open-air museum allows Han Chinese visitors (Han Chinese being the majority ethnic group) a chance to experience 'the nation in totality' (209).

In her own two chapters on museum representations of ethnic minorities, Varutti comes to some similar conclusions, while employing a methodology that differs from, and builds on, Denton's strengths. Drawing on Benedict Anderson, Varutti argues that displays of ethnic minority culture instantiate an imagined community of China as a multicultural nation (e.g. 135). It is in backing up this claim that Varutti provides her most sustained critique of museological strategies of display, and how they relate to such narratives as inclusion, hierarchy, timelessness, and gender. Whereas Denton notes the artificiality that pervades Beijing's ethnic theme park as a recently constructed 'simulacrum' (208), Varutti keenly emphasizes the artifice behind all museum representations of ethnic minorities, be they in theme parks or more conventional exhibitions. Mannequins, for instance, introduce a purposefully artificial element into displays of 'authentic' ethnic objects. The generic, front-facing mannequins encourage the viewer to identify ethnic minorities and their material culture as representative components of multicultural China (148-149; 153). This is a version of the aestheticizing strategy at work. Displays omit potentially divisive historical and social context in order to emphasize that which makes all minorities similar: their Chinese identity.

At no point in his book does Denton slow down his narrative enough to sustain the type of close looking and close analysis of display techniques that Varutti, with her museum studies background, showcases with aplomb in analyzing representations of ethnic minorities. At no point in her book does Varutti command the depth of historical knowledge and cultural context that Denton demonstrates in his analysis of the Red Crag Revolutionary Memorial Hall. These two books are well worth reading for their individual merits but they are even better together.

Neither book, however, fully answers the question of what the study of Chinese museums has to contribute to the study of museums in general. Why should the reader whose research, teaching, and/or museum work centers on Europe or America take note of this emerging subfield of Chinese museum studies? Both Varutti and Denton seem to answer this question with reference to the specificity of a historical moment: the transition from socialism to postsocialism in China and the concurrent proliferation of museums in what is currently the most populous country in the world. Neither author takes seriously enough the deeper history of Chinese heritage practices or cultures of display and what they might contribute to our thinking about 
the museum more generally. An early chapter on Chinese notions of heritage in Varutti's book is largely divorced from subsequent analysis of contemporary museums. Denton does on occasion note deep historical precedents to contemporary commemorative practices, but in his introduction, he squarely identifies the museum as a modern and initially Western phenomenon. If Chinese museums are derivative of Western counterparts, does research on them bear less interest for the museum studies scholar? I fear this may be the case, but happily I am less convinced that Chinese museums are as derivative as generally suggested by the existing literature on the subject. If future research addresses this issue, I hope it does so as part of a lively conversation between area studies and museum studies, a conversation that has already borne fruit with the two books reviewed above.

*Elizabeth Lawrence

Ball State University

References

Chakrabarty, Dipesh (2000) Provincializing Europe: Postcolonial Thought and Historical Difference, Princeton: Princeton University Press.

Harootunian, H.D. and Masao Miyoshi (2002) 'Introduction: The "Afterlife" of Area Studies,' in Harootunian and Miyoshi (eds) Learning Places: The Afterlives of Area Studies, 1-18, Durham: Duke University Press.

Macdonald, Sharon, ed. (2011) A Companion to Museum Studies, West Sussex: Blackwell Publishing Ltd. 